
The Center for South and Southeast Asia Studies of the University of California is the coordinating center for research, teaching programs, and special projects relating to the South and Southeast Asia areas on the nine campuses of the University. The Center is the largest such research and teaching organization in the United States, with more than 150 related faculty representing all disciplines within the social sciences, languages, and humanities.

The Center publishes a Monograph series, an Occasional Papers series, and sponsors a series of books published by the University of California Press. Manuscripts for these publications have been selected with the highest standards of academic excellence, with emphasis on those studies and literary works that are pioneers in their fields, and that provide fresh insights into the life and culture of the great civilizations of South and Southeast Asia.

\section{RECENT PUBLICATIONS OF THE CENTER FOR SOUTH AND} SOUTHEAST ASIA STUDIES :

Richard I. Cashman

The Myth of the LOKAMANYA:

Tilak and Mass Politics in Maharashtra

Edward Conze

The Large Sutra on Perfect Wisdom

George L. Hart, III

The Poems of Ancient Tamil:

Their Milieu and Their Sanskrit Counterparts

Tom G. Kessinger

Vilayatpur, 1848-1968:

Social and Economic Change in a North Indian Village

Robert Lingat

The Classical Law of India (translated by J. Duncan M. Derrett) 


\section{MARRIAGE AND RANK IN BENGALI CULTURE}

This volume is sponsored by the Center for South and Southeast Asia Studies, University of California, Berkeley 



\title{
RONALD B. INDEN
}

\section{MARRIAGE AND RANK IN BENGALI CULTURE}

\author{
A HISTORY OF CASTE AND CLAN \\ IN MIDDLE PERIOD BENGAL
}

UNIVERSITY OF CALIFORNIA PRESS BERKELEY · LOS ANGELES · LONDON 


\section{UNIVERSITY OF CALIFORNIA PRESS}

Berkeley and Los Angeles, California

University of California Press, Ltd. London, England

Copyright (C) 1976, by

The Regents of the University of California

ISBN 0-520-02569-5

Library of Congress Catalog Card Number : 73-85789

Printed in the United States of America 
To

Gilda, John,

and

Margaret 
